\title{
AGRITROPICA
}

Journal of Agricultural Sciences

Content is available at :

https://ejournal.unib.ac.id/index.php/jagritropica/index

ISSN 2621-217X (PRINT)

ISSN 2621-699X (ONLINE)

\section{Estimation of Indonesian Beef Price Forecasting Model}

\author{
Rimadhita Tiara Putri ${ }^{1}$, Ketut Sukiyono ${ }^{2}$, and Eko Sumartono ${ }^{2}$ \\ 1Postgraduate Program in Agribusiness, Faculty of Agriculture, University of Bengkulu \\ 2Dept. of Social Economics of Agriculture, Faculty of Agriculture, University of Bengkulu \\ Email addres : rima_dhita@yahoo.com
}

\begin{abstract}
The need for beef in Indonesia tends to increase along with fluctuated beef prices. The existence of price fluctuations will be a risk for producers and consumers. Therefore, price information is necessary, especially the future beef price and price forecasting is the answer to need. The purpose of this study is to analyze and identify the best forecasting models for domestic and international beef prices. The data used is monthly retail price data for domestic and international beef from 2013:12017:12. Four models used in this study, namely decomposition models, ARIMA, moving averages, and Single Exponential Smoothing are applied. The best forecasting method for forecasting domestic and international beef prices is the ARIMA model based on the lowest values of MAD, MAPE, and MSD.
\end{abstract}

Keywords : Forecasting, price, beef

Reference to this paper should be made as follows : Putri, R. T., K. Sukiyono and E. Sumartono. 2019. Estimation of Indonesian Beef Price Forecasting Model. Agritropica: Journal of Agricultural Science. Agritropica: Journal of Agricultural Science. 2 (1): 46-56. DOI: https://doi.org/10.31186/J.Agritropica.2.1.46-56

\section{INTRODUCTION}

Data published by Pusdatin (2016) informs the development of beef prices at the consumer level from 1983 to 2016 fluctuating and tending to increase. During this period, the price of beef at the consumer level increased by $13.17 \%$ /year. The price of beef for the last five years (2012-2016) also has a tendency to increase from the price of Rp.76,925, - up to Rp. 116,751, - with a 5-year growth of $11.08 \%$. The phenomenon of a high increase in meat prices occurred in the last five years where the highest price reached Rp.116,751 / kg in 2016. This price increase is usually due to high meat consumption on religious holidays and national holidays. However, the beef price from Eid Al-Fitr until September 2016 has never returned to its initial level. The increase in consumption which is not offset by increased production of beef causes an increase in the number of beef imports. This will cause uncertainty and instability in domestic beef prices. With the price volatility of beef, it is important to forecast to find out the estimated price for the next period to be analyzed from the previous price. The choice of forecasting method must be with the right model in order to get accurate results. Therefore it is important to forecast the price of beef using the best model.

\section{MATERIALS AND METHODS}

The data used in this article is the monthly price data for world/international beef from 2013: 12017: 12 obtained from Index Mundi. While the monthly (retail) price data for domestic / Indonesian beef from 2013:1- 
2017:12 was obtained from the Food and Agriculture Organization (FAO).

There are 4 (four) models used to forecast the prices of Indonesian beef and international beef. In detail these models will be explained as follows:

\section{Decomposition Model}

In the decomposition method, there are two models, namely additive and multiplicative decomposition. Additive and multiplicative decomposition models can be used to predict the trend, seasonal and cycle factors. The simple average decomposition method assumes the additive model, while the ratio decomposition method on the moving average (classical decomposition) and the Census II method assumes a multiplicative model. Mathematically can be written:

$$
Y_{x}=T_{x}+S_{x}+C_{x}+I_{x}
$$
... (additive

model)

$$
Y_{x}=T_{x} X S_{x} X C_{x} X I_{x}
$$

.(multiplicative

model)

where $Y_{x}=$ periodic data period $x, T x=$ period trend data $x, S_{x}=$ seasonal factor (index ) period $x, C_{x}=$ cyclic period $x, I_{x}=$ error factor $\mathrm{x}$.

Several studies have used decomposition models for forecasting research, such as Indira's research (2018) for forecasting the number of aircraft passengers.

\section{ARIMA Model}

The Autoregressive Integrated Moving Average (ARIMA) is often also called the Box-Jenkins time series method. ARIMA is very good for shortterm forecasts, while for long-term forecasts the accuracy of its estimates is not good. Usually, it will tend to be flat for a fairly long period. ARIMA can be interpreted as a combination of two models, namely the autoregressive (AR) model which is integrated with the Moving Average (MA) model. The ARIMA model is generally written with ARIMA notation $(p, d, q)$. P is the degree of AR process, $\mathrm{d}$ is the differentiation order and $\mathrm{q}$ is the degree of MA process (Nachrowi, 2006). The ARIMA model is a model that completely ignores independent variables in making estimates. ARIMA uses the past and present values of the dependent variable to produce accurate short-term forecasts. ARIMA is suitable if time series observations are statistically related to each other (dependent). ARIMA (p, d, q) can be written as follows:

$$
\mathrm{X}_{\mathrm{t}}=\mu^{\prime}+\emptyset_{1} \sum_{i=1}^{i=p} \mathrm{X}_{\mathrm{t}-\mathrm{p}}+\mu^{\prime}+\theta_{1} \sum_{k=1}^{k=q} \mathrm{e}_{\mathrm{t}-\mathrm{k}}
$$

Where: $\mathrm{t}=1.2,3, \ldots . . . x \mathrm{t}, \quad \varnothing 1$ and $\Theta 1=$ coefficient value

Research of Aziz Syarfi, Ahmad Sayuti \& Mustakim (2017), Elvani Sendy, Anis R \& Rizky (2016) and Herawaty (2016), are among researchers who use the ARIMA model for forecasting.

\section{Moving Average Model}

The model Moving Average (MA) is an indicator that is often used in technical analysis that shows the average value of data over a given period. The averaged data is time-dependent data. Moving Average is usually used in stock/forex technical analysis, price to measure momentum and determine the possible area of support and resistance. The previous research using the model Moving Average is Nurlifa \& Kusumadewi (2017) research for sales forecasting, Seftiansyah Eko, Desi Y, Syaripuddin (2013) for cash forecasting, and Andriana \& Susanto (2017) use this 
model for forecasting the amount of production.

The MA method can be formulated as follows:

$$
A_{t}=\left(D_{t}+D_{t-1}+D_{t-2}+\cdots .+D_{t-N+1}\right) / N
$$

Where $D=$ Time series data (data series), $\mathrm{N}=$ Total average number of periods, $A_{t}$ $=$ prediction in period $t+1$.

\section{Single Exponential Smoothing Model}

Exponential smoothing model is a procedure that repeats continuously calculation that uses the latest data. Each data is given a weight, where the weight used is symbolized by a. The a symbol can be determined freely, which reduces forecast error. The smoothing constant value, $a$, can be selected between the values of 0 and, because it applies: $0<a$ $<1$ (Garpersz, 2005). The model Exponential Smoothing was used by Suryani \& Wahono (2015) in his research on forecasting gold prices.

Mathematically, the exponential writing equation is as follows:

$$
S t+1=\alpha X t+(1-\alpha) S
$$

Where St $+1=$ Forecast value for the next period, $a=$ Writing constant $(0-1)$, $\mathrm{Xt}=$ Data in period $\mathrm{t}, \mathrm{St}=$ Old writing value or starting average until $t-1$ period.

\section{Model Selection}

The forecasting method aims to produce optimum predictions that do not have a large error rate. If the error rate is getting smaller, the forecasting results will be closer to the actual value. Accurate projection results are predictions that can minimize forecasting errors. The best model is selected from the model that has the smallest MAPE, MSE and MAD values.
1. Mean Absolute Percentage Error (MAPE)

This approach is very useful if the forecasting variable size is an important factor in evaluating the accuracy of the forecasting. MAPE provides an indication of how much forecasting error is compared to the actual value of the data series.

$$
\text { MAPE }=\frac{\sum_{i=1}^{n} P E_{i}}{n}
$$

Where: $\mathrm{MAPE}=$ absolute percentage error average value, $\mathrm{n}=$ number of time periods of data

\section{Average Square Error (Mean Square Error = MSE) \\ MSE is calculated by summing the} squares of all forecasting errors at each period and dividing it by the number of forecasting periods. Mathematically, MSE is formulated as follows (Nasution \& Prasetyawan, 2008):

$$
\text { MSE }=\frac{(A t-F t)^{2}}{n}
$$

where: At=Actual Demand in a period $-t$, $\mathrm{Ft}=$ Demand forecasting (Forecast) in period- $t, n=A m o u n t$ forecasting period involved.

\section{The average Absolute Deviation (MAD)}

MAD is the average absolute error over a given period regardless of whether the forecasting results are greater or smaller than the reality. Mathematically, MAD is formulated as follows (Nasution \& Prasetyawan, 2008):

$$
\mathrm{MAD}=\frac{(A t-F t)^{2}}{n}
$$

where: At=Actual Request in a period $-t$, $\mathrm{Ft}=$ Demand forecasting (Forecast) in period-t, $n=$ Number of forecasting periods which are involved. 


\section{RESULTS AND DISCUSSION}

\section{Description of Beef Prices}

Prices of beef prices used are domestic beef retail prices and international beef prices from 2013:12017: 12 (60 observations). Descriptively domestic and international beef prices can be seen in Table 1, while graphically can be seen in Figure 1.
From table 1, the average value of domestic beef prices is Rp. 104,934, while the average value of international beef prices is $\$ 4.41$. The value of the standard deviation of domestic beef prices is 9,659.9571, while the standard deviation value of international beef prices is 0.516868 .

Table 1. Descriptive Data on Domestic and International Beef Prices

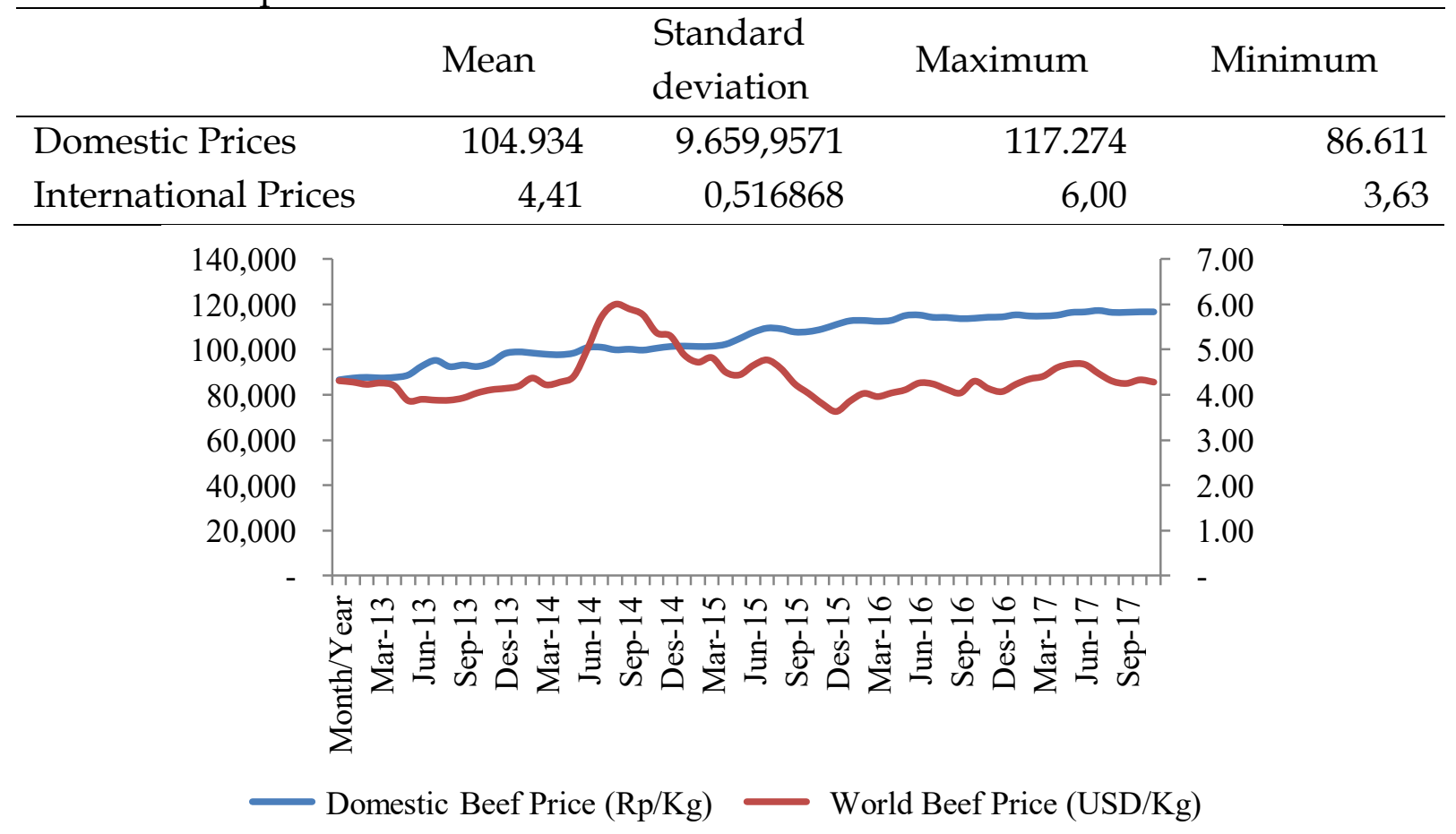

Figure 1. Domestic Beef Price and World Beef Price

\section{Estimated Forecasting Model}

The best forecasting model will be used as a reference for forecasting beef prices. In this paper, four forecasting models are used, namely Decomposition, Moving Average, ARIMAl, and Single Exponential Smoothing. The model was analyzed using Minitab 18 and SPSS 16. The models from Forecasting for beef prices are as follows.

\section{Decomposition Model}

Decomposition Model is used to predict data containing trend, seasonal, and cycle factors. In general, there are two types of decomposition models namely additive decomposition and multiplicative decomposition. Forecasting results using decomposition models for domestic beef prices and international beef prices can be seen in figures 2 and 3 as follows: 


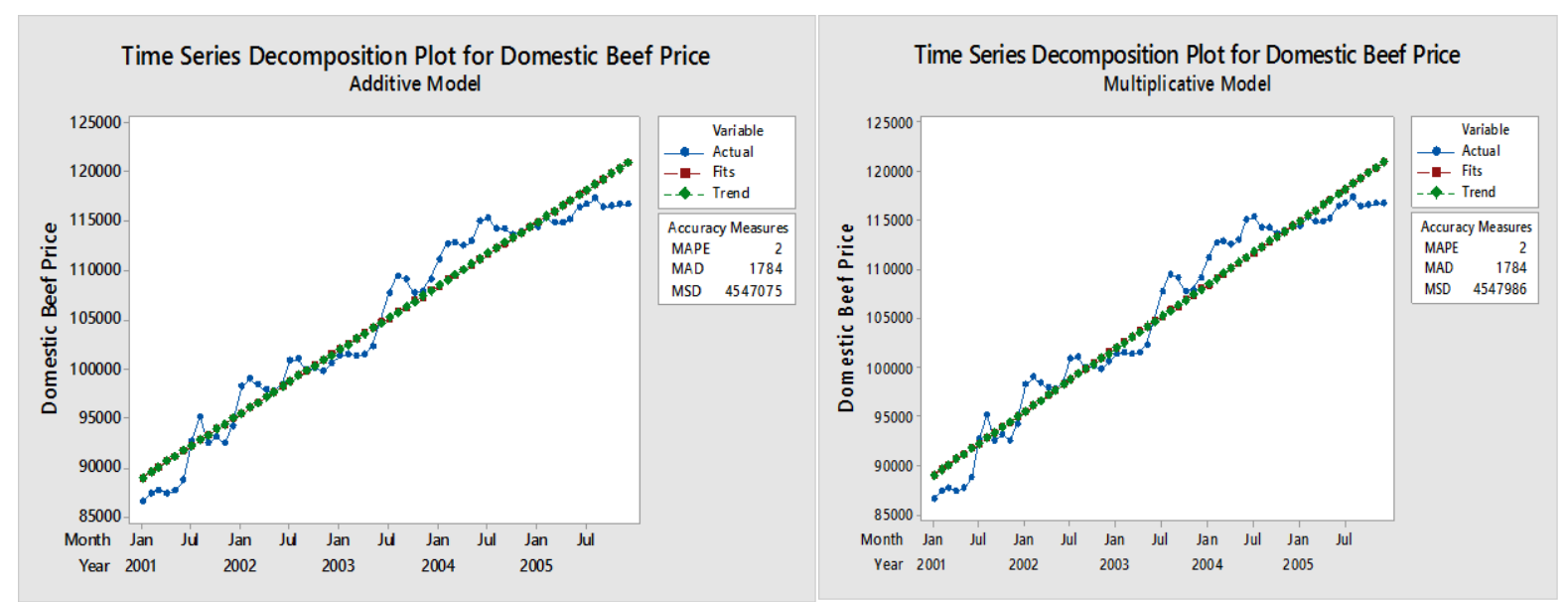

Figure 2. Additive and multiplicative decomposition of Domestic Beef Price
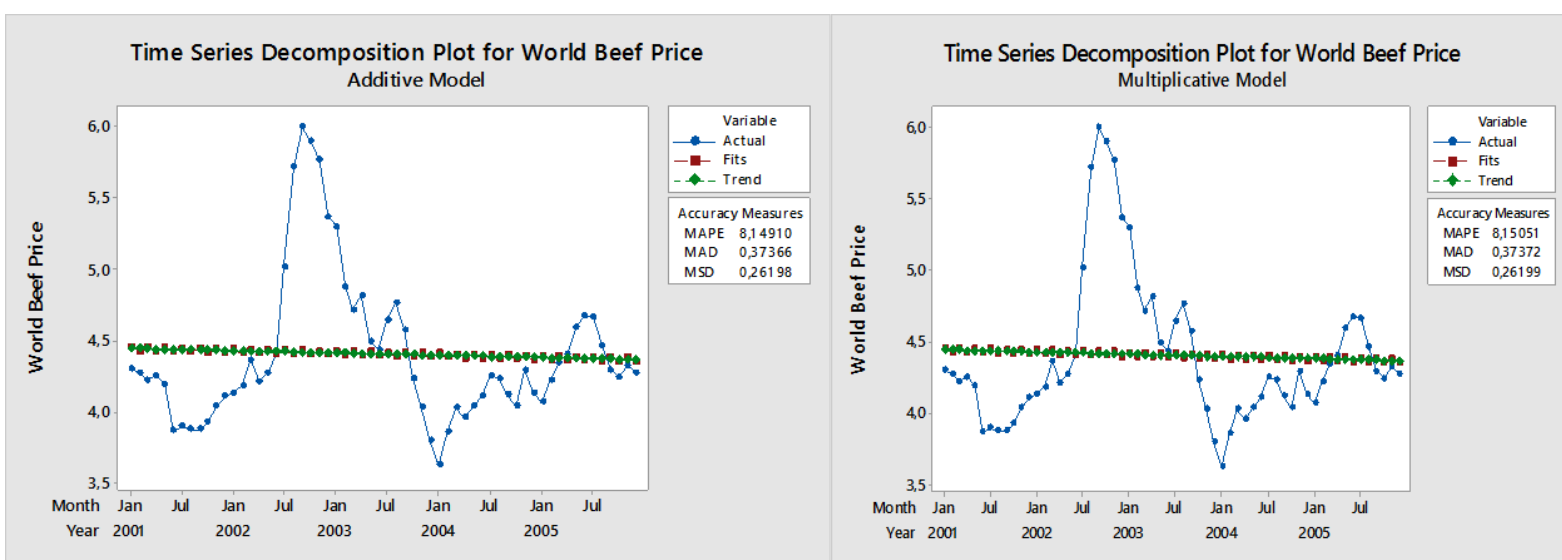

Figure 3. Additive and multiplicative decomposition World Beef Price

From Figure 2 and Figure 3, the decomposition model of domestic beef prices, both additive decomposition and multiplicative decomposition have the same tend pattern. Likewise, for the decomposition model of international beef price data, both additive decomposition and multiplicative decomposition also have the same pattern.

Furthermore, it can be seen the comparison result of the second estimation models of decomposition of the additive and multiplicative decomposition in Table 2 as follows:

Table 2. Comparison of Results of Estimation Model Decomposition

\begin{tabular}{llrrr}
\hline \multirow{2}{*}{ Data } & \multirow{2}{*}{ Decomposition Type } & \multicolumn{3}{c}{ Accuracy Measure } \\
\cline { 3 - 5 } & & MAPE (\%) & MAD & \multicolumn{1}{c}{ MSD } \\
\hline \multirow{3}{*}{ Domestic price } & Multiplicative & 2 & 1784 & 4547075 \\
& Selection & 2 & 1784 & 4547986 \\
& Additives & Inconclusive & Inconclusive & Additives \\
\hline \multirow{2}{*}{ Internasional } & Multiplicative & 8,14910 & 0,37366 & 0,26198 \\
price & Selection & 8,15051 & 0,37372 & 0,26199 \\
& & Additives & Additives & Additives \\
\hline
\end{tabular}


In Table 2, the results of the decomposition analysis on domestic beef prices decomposition of the best models are models additive decomposition with MSD values smaller than MSD from multiplicative decomposition models, while the MAPE and MAD values of each model are the same. From this additive decomposition model, forecasting the price of dominate beef in the next period (61st period) is Rp. 121,327, -.

For the results of decomposition analysis on international beef prices, the best decomposition model is an additive decomposition model. This conclusion is based on the smaller MAPE, MAD and MSD values that are owned by the Additive decomposition model. From this additive decomposition model, forecasting international beef prices in the next period (61st period) is $\$ 4.38$.

\section{ARIMA Model}

The Arima model will first see data that is used stationary or not.data can Time series not be separated from autocorrelation which causes data to be not stationary. Therefore the data to be analyzed must be ensured to be stationary both for variety and average. To find out the stationary data on the variety, transformation needs to be done by using Box-Chox Transformation, where the value of the Rounded Value must be equal to 1 . If the Rounded Value value is not equal to 1 then the transformation of the Rounded Value is 1.

For seeing the stationary data on the average can be seen in the autocorrelation and partial autocorrelation functions in figure 4 and 5 as follows:
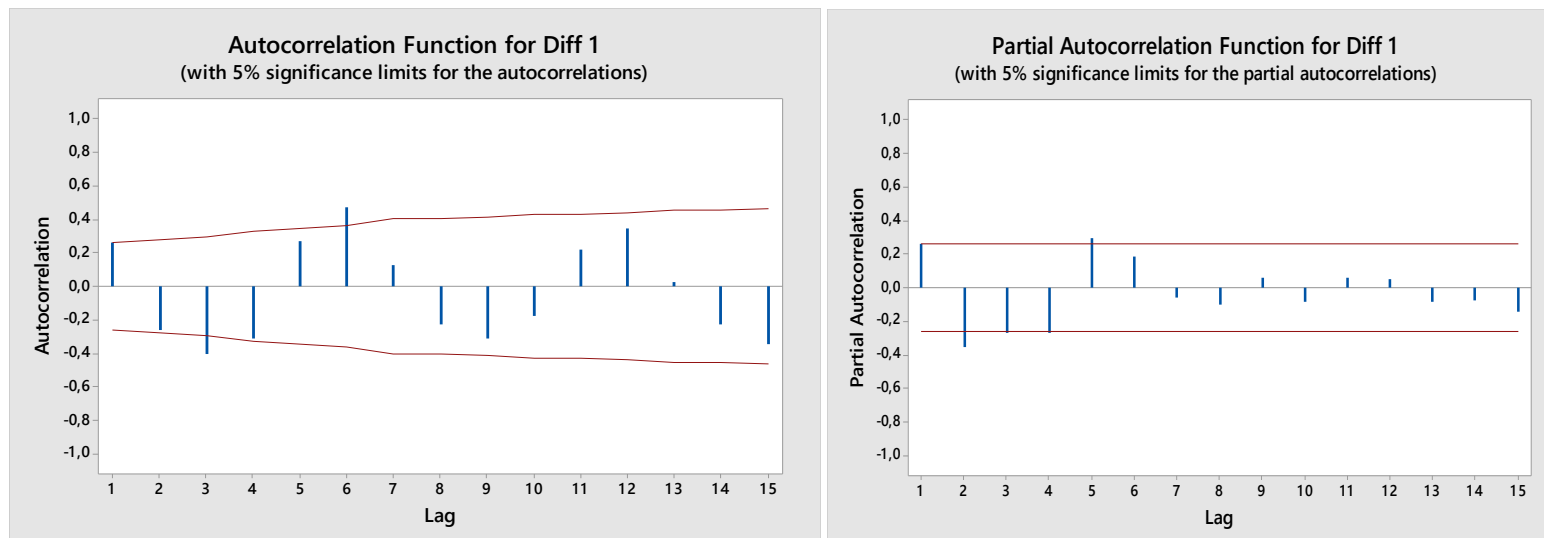

Figure 4. Autocorrelation and Partial Autocorrelation Function Domestic Beef Price
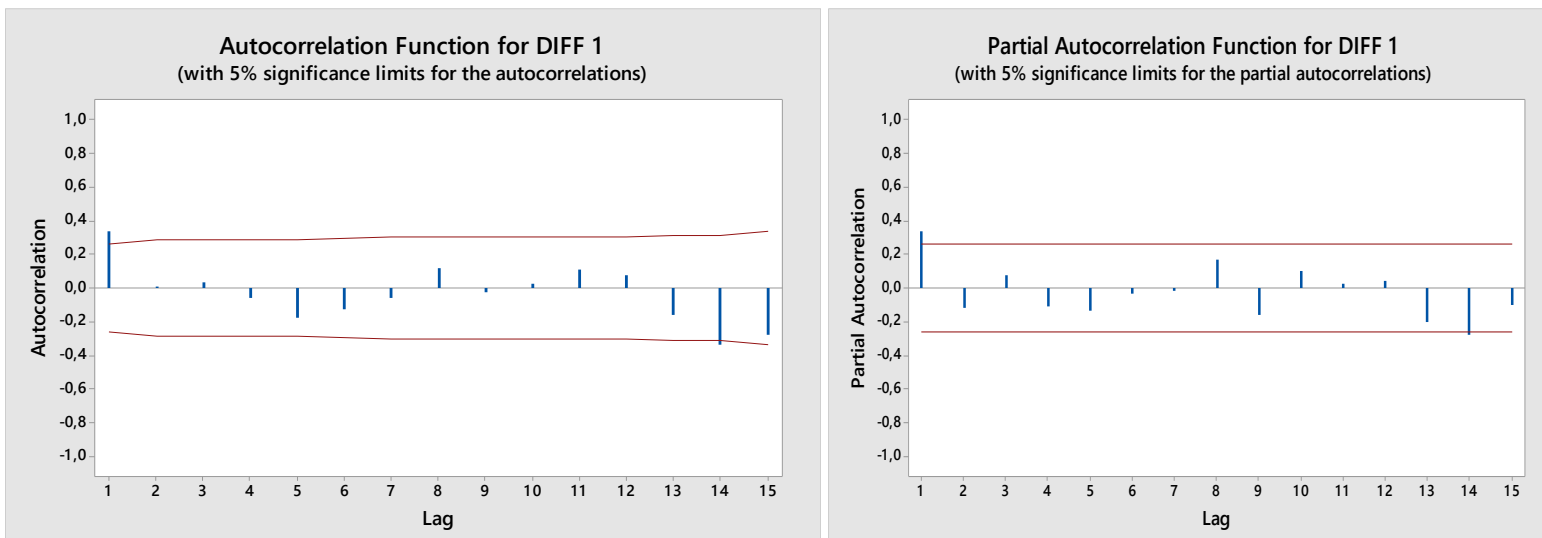

Figure 5. Autocorrelation and Partial Autocorrelation Function World Beef Price 
In Autocorrelation Function (ACF) and Partial Autocorrelation Function (PACF), Domestic and International Beef Prices after data has experienced differencing 1 time. This shows that the ACF and PACF data is stationary because the lag that comes out of the line confidence interval does not exceed 3 and the data can be continued to be estimated using the ARIMA model.

The price of domestic beef is obtained by the Arima model $(5,1,0)$ with the forecast price for the 61st period amounting to Rp.117,729. Results of the estimation of Arima models can be seen in Table 3.

Table 3. The value of MAPE, MAD, and MSD ARIMA model of Domestic Beef price

\begin{tabular}{cccc}
\hline \multirow{2}{*}{ ARIMA Type } & \multicolumn{3}{c}{ Domestic Beef Price } \\
\cline { 2 - 4 } & MAPE $(\%)$ & MAD & MSD \\
\hline$(1,1,0)$ & 0,837 & 0,857 & 1,396 \\
\hline$(2,1,0)$ & 0,785 & 0,804 & 1,245 \\
\hline$(3,1,0)$ & 0,751 & 0,772 & 1,183 \\
\hline$(4,1,0)$ & 0,732 & 0,757 & 1,099 \\
\hline$(5,1,0)$ & $\mathbf{0 , 7 0 6}$ & $\mathbf{0 , 7 2 9}$ & $\mathbf{1 , 0 0 5}$ \\
\hline$(0,1,1)$ & 0,829 & 0,848 & 1,321 \\
\hline$(0,1,2)$ & 0,816 & 0,840 & 1,264 \\
\hline$(0,1,3)$ & 0,790 & 0,813 & 1,257 \\
\hline$(0,1,4)$ & 0,737 & 0,761 & 1,140 \\
\hline$(1,1,1)$ & 0,816 & 0,837 & 1,310 \\
\hline$(1,1,2)$ & 0,784 & 0,805 & 1,283 \\
\hline$(2,1,1)$ & 0,761 & 0,783 & 1,182 \\
\hline$(2,1,2)$ & 0,796 & 0,818 & 1,331 \\
\hline
\end{tabular}

For international beef prices, the results of the estimation of the Arima model can be seen in Table 4 with the
Arima model $(2,1,3)$ with the forecast price for the 61st period amounting to $\$$ 4,26 .

Table 4. MAPE, MAD, and MSD values of ARIMA models of International Beef Price

\begin{tabular}{cccc}
\hline \multirow{2}{*}{ ARIMA Type } & \multicolumn{3}{c}{ International Beef Price } \\
\cline { 2 - 4 } & MAPE $(\%)$ & MAD & MSD \\
\hline$(1,1,0)$ & 2,9860 & 0,1337 & 0,03364 \\
\hline$(2,1,0)$ & 2,9564 & 0,1316 & 0,03379 \\
\hline$(3,1,0)$ & 2,9504 & 0,1313 & 0,03440 \\
\hline$(4,1,0)$ & 2,8793 & 0,1282 & 0,03466 \\
\hline$(5,1,0)$ & 2,8322 & 0,1263 & 0,03360 \\
\hline$(0,1,1)$ & 2,9854 & 0,1333 & 0,03385 \\
\hline$(0,1,2)$ & 2,9663 & 0,1322 & 0,03432 \\
\hline$(0,1,3)$ & 2,9660 & 0,1323 & 0,03378 \\
\hline$(1,1,1)$ & 2,9679 & 0,1323 & 0,03439 \\
\hline$(1,1,2)$ & 2,9688 & 0,1324 & $\mathbf{0 , 0 3 2 3 3}$ \\
\hline$(2,1,1)$ & 2,8838 & 0,1285 & 0.03291 \\
\hline$(2,1,2)$ & 2,8816 & 0,1284 & 0,03328 \\
\hline$(2,1,3)$ & $\mathbf{2 , 8 0 8 7}$ & $\mathbf{0 , 1 2 5 5}$ & 0.03351 \\
\hline$(3,1,2)$ & 2,8775 & 0,1284 &
\end{tabular}




\section{Moving Average}

On the Moving Average model at the price of domestic beef and international beef prices can be seen from the estimation results in table 5. For the price of MA 1 domestic beef type is the best type with MAPE values (1\%), MAD (907) and MSD (1701792) with estimated meat prices domestic cattle in the 61st period is Rp. 116,680, -. Similar to the price of domestic beef, the best price of MA type international beef is type 1 with MAPE values (3.3159\%), MAD (0.1500) and MSD (0.0408) with estimated beef prices international in the 61 st period was $\$ 4.28$.

Table 5. Results of Estimated Moving Average Model

\begin{tabular}{|c|c|c|c|c|c|c|c|c|}
\hline \multirow[b]{2}{*}{ Type } & \multirow{2}{*}{$\begin{array}{l}\text { Forecastin } \\
\text { g Value } \\
(\mathrm{Rp} / \mathrm{kg})\end{array}$} & \multicolumn{3}{|c|}{ Domestic Beef Price } & \multirow{2}{*}{$\begin{array}{l}\text { Forecastin } \\
\text { g Value } \\
\text { (USD/kg) }\end{array}$} & \multicolumn{3}{|c|}{ International Beef Price } \\
\hline & & $\begin{array}{c}\text { MAPE } \\
(\%)\end{array}$ & MAD & MSD & & $\begin{array}{c}\text { MAPE } \\
(\%)\end{array}$ & MAD & MSD \\
\hline MA 1 & 116.680 & 1 & 907 & 1701792 & 4,28 & 3,3159 & 0,1500 & 0,0408 \\
\hline MA 2 & 116.669 & 1 & 1158 & 2786664 & 4,30 & 4,2050 & 0,1919 & 0,0706 \\
\hline MA 3 & 116.604 & 1 & 1327 & 3775843 & 4,28 & 4,9563 & 0,2278 & 0,1027 \\
\hline MA 4 & 116.559 & 1 & 1476 & 4634379 & 4,29 & 5,7981 & 0,2667 & 0,1356 \\
\hline MA 5 & 116.702 & 2 & 1648 & 5401633 & 4,32 & 6,5550 & 0,3020 & 0,1669 \\
\hline
\end{tabular}

\section{Methods single Exponential smoothing}

In a single exponential smoothing method is performed using a value of $0<a<1$. The comparison of the estimation results from the method is single exponential smoothing used for the value of a ranging from 0.1 to 0.9 can be seen in table 6 as follows:

Table 6. Comparison of Estimated Results of the method Single Exponential Smoothing

\begin{tabular}{|c|c|c|c|c|c|c|c|c|}
\hline \multirow[b]{2}{*}{ a } & \multirow{2}{*}{$\begin{array}{c}\text { Forecasting } \\
\text { Value } \\
(\mathrm{Rp} / \mathrm{kg})\end{array}$} & \multicolumn{3}{|c|}{ Domestic Beef Price } & \multirow{2}{*}{$\begin{array}{c}\text { Forecasting } \\
\text { Value } \\
\text { (USD/kg) }\end{array}$} & \multicolumn{3}{|c|}{ International Beef Price } \\
\hline & & $\begin{array}{c}\text { MAPE } \\
(\%)\end{array}$ & MAD & MSD & & $\begin{array}{c}\text { MAPE } \\
(\%)\end{array}$ & MAD & MSD \\
\hline 0,1 & 114.709 & 4 & 4556 & 25580172 & 4,342 & 6,7688 & 0,3121 & 0,2251 \\
\hline 0,2 & 116.194 & 2 & 2417 & 8864416 & 4,354 & 5,9512 & 0,2736 & 0,1624 \\
\hline 0,3 & 116.496 & 2 & 1645 & 5109547 & 4,343 & 5,2849 & 0,2430 & 0,1219 \\
\hline 0,4 & 116.598 & 1 & 1277 & 3660963 & 4,322 & 4,7634 & 0,2187 & 0,0962 \\
\hline 0,5 & 116.635 & 1 & 1138 & 2935308 & 4,306 & 4,3690 & 0,1998 & 0,0788 \\
\hline 0,6 & 116.650 & 1 & 1070 & 2503590 & 4,296 & 4,0646 & 0,1853 & 0,0663 \\
\hline 0,7 & 116.660 & 1 & 1016 & 2211298 & 4,290 & 3,7896 & 0,1723 & 0,0570 \\
\hline 0,8 & 116.669 & 1 & 974 & 1994425 & 4,287 & 3,5819 & 0,1625 & 0,0499 \\
\hline 0,9 & 116.676 & 1 & 937 & 1824831 & 4,284 & 3,4214 & 0,1550 & 0,0445 \\
\hline
\end{tabular}

From table 6 , it can be seen that the estimation results of the method Single Exponential Smoothing for data on domestic and international beef prices are the best using the value $a=$ 0.9. For domestic beef prices, MAPE 
values (1\%), MAD (937), and MSD (1824831) were obtained and the value of forecasting domestic beef prices for the 61st period was Rp. 116,676, -. Whereas for international beef prices, MAPE values (3.4214\%), MAD (0.1550), and MSD (0.0445) were obtained and the value of forecasting domestic beef prices for the 61st period was \$ 4.284 .

\section{Selection of the most accurate models}

In this article four forecasting models are used, namely Decomposition Model, Moving Average, ARIMA Model, and Model Single Exponential Smoothing. Selection of the best model by looking at the values of MAPE, MAD, and MSD which have the lowest value. The results of the comparison of MAPE, MAD, and MSD values from each model of domestic beef prices and international beef prices can be seen in Table 7 below:

Table 7. Comparison of Forecasting Model

\begin{tabular}{|c|c|c|c|c|}
\hline \multirow{2}{*}{ Forecasting Model } & \multicolumn{3}{|c|}{ Accuracy Measure } & \multirow[t]{2}{*}{ Conclusion } \\
\hline & MAPE (\%) & MAD & MSD & \\
\hline \multicolumn{5}{|l|}{ Harga Domestic } \\
\hline Moving Average (1) & 1 & 907 & 1701792 & \multirow{4}{*}{$\operatorname{ARIMA}(5,1,0)$} \\
\hline Dekomposisi Aditif & 2 & 1784 & 4547075 & \\
\hline $\begin{array}{l}\text { Single Exponential } \\
\text { Smoothing }(\mathrm{a}=0,9)\end{array}$ & 1 & 937 & 1824831 & \\
\hline ARIMA $(5,1,0)$ & 0,706 & 0,729 & 1,005 & \\
\hline \multicolumn{5}{|l|}{ Harga Internasional } \\
\hline Moving Average (1) & 3,3159 & 0,1500 & 0,0408 & \\
\hline ARIMA $(2,1,3)$ & 2,8087 & 0,1255 & 0,03328 & \\
\hline $\begin{array}{l}\text { Dekomposisi Aditif } \\
\text { Single Exponential }\end{array}$ & 8,14910 & 0,37366 & 0,26198 & $\operatorname{ARIMA}(2,1,3)$ \\
\hline Smoothing $(a=0,9)$ & 3,4214 & 0,1550 & 0,0445 & \\
\hline
\end{tabular}

From Table 7 it can be seen that the selection of the best model for price data ( retail) Domestic is the ARIMA model $(5,1,0)$ and world beef is the ARIMA model $(2,1,3)$ with the smallest comparison of MAPE, MAD, MSD values between other models. This is in line with Sukiyono et al (2018) 's study of accurate cocoa price forecasting models, where the best model of the study is the ARIMA model. In addition to the research of Novanda et al (2018) regarding the forecasting of the world and domestic coffee prices, the Arima model is also the best model with the smallest MAPE, MAD, MSD values delivered by other models.

\section{CONCLUSION}

The best model for forecasting (retail) domestic and global beef prices is the ARIMA model. This is because the model has the lowest MAPE, MAD, MSD among the other models.

\section{REFERENCES}

Andriana \& Susanto. 2017. Peramalan Jumlah Produksi Teh Menggunakan Metode Single 
Moving Average (SMA). Teknik Informatika, Unikom. Bandung.

Astawan, P. D. (2004). Pentingnya Mengkonsumsi Daging. http:// peternakantaurus.wordpress. com/2010/07/26/pentingnya mengkonsumsi-daging. Diakses pada Pukul 10.26 WITA. Tanggal 11 Juli 2015. Kota Samarinda.

Dimyati, A. 2013. Impor Daging Sapi: Sejauh Mana Keterlibatan Bea dan Cukai. Artikel. PUSDIKLAT.

Aziz, S., A. Sayuti \& Mustakim. 2017. Penerapan Metode ARIMA untuk Peramalan Pengunjung Perpustakaan UIN Suska Riau. Fakultas Sains dan Teknologi, UIN. Riau.

Elvani, S. P., Utary, A. R., \& Yudaruddin, R. 2017). Peramalan jumlah produksi tanaman kelapa sawit dengan menggunakan metode ARIMA (Autoregressive Integrated Moving Average). Jurnal Manajemen, 8(1), 95112.

Gaspersz, V. 2005. Sistem Manajemen Kinerja Terintegrasi Balanced Scorecard Dengan Six Sigma Untuk Organisasi Bisnis dan Pemeritah. Jakarta: Gramedia Pustaka Utama.

Indira, D. 2018. Analisis Peramalan Time Series Metode Dekomposisi Meramalkan Jumlah Penumpang Keberangkatan Internasional di Bandara Internasional SoekarnoHatta Jakarta Berkaitan dengan Terminal 3 Ultimate. Itera

Nasution, A. H., dan Prasetyawan, Y. (2008). Perencanaan \& Pengendalian Produksi. Edisi Pertama. Graha Ilmu, Yogyakarta.

Nachrowi, N.D, Usman, H. 2006. Pendekatan Populer dan Praktis Ekonometrika Untuk Analisis
Ekonomi dan Keuangan, Lembaga Penerbit Fakultas Ekonomi Universitas Indonesia, Jakarta.

Novanda, Rizky et al (2018). A comparison of Various Forecasting Techniques for Coffee Price. IOP Publishing. Diakses dari https://www.researchgate.net/publi cation/329490410_A_Comparison_of _Various_Forecasting_Techniques_fo r_Coffee_Prices

Nurlifa, A., \& S. Kusumadewi. 2017. Sistem Peramalan Jumlah Penjualan Menggunakan Metode Moving Average Pada Rumah Jilbab Zaky. INOVTEK Polbeng-Seri Informatika. 2(1): 18-25.

Pusdatin. 2016. Outlook Daging Sapi Komoditas Pertanian Subsektor Peternakan. Jakarta

Pusdatin. 2017. Outlook Daging Sapi Komoditas Pertanian Subsektor Peternakan. Jakarta

Seftiansyah, E., Y. Desi, dan Syaripuddin. 2013. Peramalan Kas Bank Central Asia, TBK Samarinda Tahun 2012 Dengan Menggunakan Metode Dekomposisi dan Double Moving Average. Jurnal Eksponensial. 4(2): 125-129

Sukiyono, Ketut et al. 2018. Selecting an Accurate Cacao Price Forecasting Model. IOP Publishing. Diakses dari https://www.researchgate.net/publi cation/329490444_Selecting_an_Accu rate_Cacao_Price_Forecasting_Model $\angle$ download

Suryani, I., \& Wahono, R. S. (2015). Penerapan Exponential Smoothing untuk Transformasi Data dalam Meningkatkan Akurasi Neural Network pada Prediksi Harga Emas. Journal of Intelligent Systems. 1(2). 67-75. 